Vol 1 No 2 (2018) 245-255 P-ISSN 2620-295 E-ISSN 2747-0490 DOI: 1047467/elmal.v2i2.544

\title{
Pengaruh Kepercayaan dan Kesehatan Terhadap Kesadaran Masyarakat Mengkonsumsi Makanan dan Produk Halal
}

\author{
Sri Wahyuni Hasibuan', Yaumul Khair Afif², Azkiya Ilma Novliza3, Sumiati4 \\ 1,2Dosen STAIS Jam'iyah Mahmudiyah Tanjung-Pura Langkat, Sumatera Utara, Indonesia \\ ${ }^{3}$ 'Mahasiswa STAIS Jam'iyah Mahmudiyah Tanjung-Pura Langkat Sumatera Utara, \\ Indonesia \\ yuni.hsb@gmail.com ${ }^{1}$
}

\begin{abstract}
Halal food and product is a food that is free from what is forbidden, delicious and nutritious, the product does not contain najis, harmful ingredients, and is clean from dirt that can provide the values of goodness, health, safety, purity, beauty, and not cause harm to others but cause benefits for the ummah both materially and spiritually. So far, the general public views halal food and products only for Muslim consumers. In fact, halal food and products can be consumed by all consumer backgrounds, because this brand is holistic, namely a cosmetic brand that is not separated from one's beliefs. So based on this phenomenology, this study aims to analyze the influence of trust and health on public awareness of consuming halal food and products. This study was analyzed by quantitative research methods using the SPSS approach. This research found that beliefs and health affect consciousness. So it is recommended for stakeholders to build consumer awareness dynamically such as through socialization to the public about halal food and products.
\end{abstract}

Keywords: Halal food and products, trust, health, and awareness

\section{ABSTRAK}

Makanan dan produk halal adalah suatu makanan yang terhindar dari yang diharamkan, lezat dan bergizi, produk tidak mengandung najis, bahan-bahan yang berbahaya, serta bersih dari kotoran yang dapat memberi nilai-nilai kebaikan, kesehatan, keamanan, kesucian, keindahan, serta tidak menimbulkan kemudratan bagi yang lainnya akan tetapi menimbulkan kemaslahatann untuk ummat baik secra materil maupun spiritual. Sejauh ini masyarakat umum memandang makanan dan produk halal hanya untuk konsumen muslim. Kenyataannya makanan dan produk halal dapat dikonsumsi semua latar belakang konsumen, karena brand ini bersifat holistik yaitu merek kosmetik yang tidak dipisahkan dari kepercayaan seseorang. Maka berdasarkan fenomenologi tersebut penelitian ini bertujuan untuk menganalisa pengaruh kepercayaan dan kesehatan terhadap kesadaran masyarakat mengkonsumsi makanan dan produk halal. Penelitian ini dianalisis dengan metode penelitian kuantitatif menggunakan pendekatan SPSS. Riset ini menemukan bahwa kepercayaan dan kesehatan berpengaruh terhadap kesadaran. Maka disarankan bagi stakeholder membangun kesadaran konsumen secara dinamis seperti melalui sosialisasi terhadap masyarakat tentang makanan dan produk halal.

Kata Kunci: Makanan dan produk halal, kepercayaan, kesehatan, dan kesadaran 


\section{Vol 1 No 2 (2018) 245-255 P-ISSN 2620-295 E-ISSN 2747-0490 DOI: $1047467 /$ elmal.v2i2.544}

\section{PENDAHULUAN}

Indonesia sebagai Negara yang memiliki penduduk mayoritas muslim dan memiliki sumberdaya alam berpotensi sebagai pusat industri halal dunia. Selain itu Indonesia didukung secara geografis yaitu berpotensi sebagai persinggahan lalu lintas perdagangan Internasional baik melalui jalur udara, laut maupun darat. Dengan memanfaatkan potensi budaya, sumber daya alam dan geografis ini, Indonesia seyogianya dapat mengembangkan industri halal sebagai salah satu faktor yang dapat mendorong pembangunan ekonomi. Adapun potensi produk halal tersebut yaitu halal food, halal finance and business, halal tourism, Islamic fashion, halal cosmetics, and integrated halal zone.

Berdasarkan laporan state of global Islamic economy, tingkat pengeluaran umat muslim mengalami pertumbuhan dari tahun 2018 sampai 2019 sebesar 3,2\%. Umat muslim membelanjakan 2,02 milyar dolar untuk makanan, farmasi, kosmetik, fesyen, perjalanan dan media rekreasi. Disamping itu, aset keuangan syariah diperkirakan telah mencapai 2. 88 triliun dolar di tahun 2019.

Secara global Indonesia menduduki peringkat ke lima sebagai pemasok produk halal adapun yang menduduki peringkat pertama adalah Negara Malaysia, kedua UAE, ketiga Bahrain, keempat Saudi Arabia. Harapannya Indonesia dapat menjadi pusat industri halal dunia karena Indonesia memiliki potensi pasar yang besar, yaitu $87 \%$ dari total 267 juta jiwa merupakan penduduk muslim.

Adapun salah satu yang menjadi prioritas adalah peningkatan pangsa pasar produk makanan dan minuman. Karena Indonesia belum berada di peringkat 10 besar. Padahal sektor ini dapat menjadi penyumbang terbesar ekonomi halal. Mengejar ketertinggalan ini perlu kerja keras dengan mengintegrasikan aspek-aspek yang paling mempengaruhi berkembangnya suatu industri. Mulai dari aspek yang paling besar sampai yang terendah.

Kepercayaan masyarakat pada makanan dan produk halal dapat meningkat atau dapat menurun, hal ini sangat tergantung dengan kesadaran halal. (Ambali, A. R., \& Bakar, A. $N, 2014$ ) dalam temuannya sejalan dengan pendapat tersebut yaitu bahwa faktor yang mempengaruhi kesadaran halal kepercayaan. Kepercayaan meningkat dapat disebabkan oleh pengetahuan, pengalaman maupun pembelajaran yang didapatkan melalui interaksi sosial baik langsung atau sosial media. Sedangkan kepercayaan menurun dapat disebabkan oleh pengetahuan yang rendah, pengalaman yang sedikit, serta minimnya berinteraksi dengan orang lain. Banyaknya isu dan fenomena tentang industri halal, peneliti membatasi penelitian ini yaitu bahwa sadar kepada makanan dan produk halal kemungkinan dapat dipengaruhi oleh kepercayaan dan kesehatan. Maka adapun judul penelitian ini adalah Pengaruh Kepercayaan dan Kesehatan Terhadap Kesadaran Masyarakat Mengkonsumsi Makanan dan Produk Halal. 
Vol 1 No 2 (2018) 245-255 P-ISSN 2620-295 E-ISSN 2747-0490 DOI: 1047467/elmal.v2i2.544

\section{TINJAUAN LITERATUR}

\section{A. Makanan dan Produk Halal}

Menurut (al-Qardhawi, 1997) konsumsi melingkupi semua pemakaian dan pemanfaatan barang dan jasa untuk memenuhi kebutuhan manusia dalam kehidupan sehari-hari. Hal ini menunjukkan konsumsi tidak hanya makan dan minum, tetapi termasuk pada produk-produk lainnya seperti kosmetik, obat-obatan, dan lain-lain. Dalam konsep Islam diwajibkan bagi kaumnya memakan dan menggunakan barang dan jasa yang halal. Fatwa (MUI, 2009) menimbang bahwa makanan, minuman, obat-obatan, kosmetika dan laii-lain yang akan dikonsumsi atau dipergunakan oleh umat Islam wajib diperhatikan dan diyakini kehalallan dan kesuciannya. Firman Allah SWT telah menjelaskan barang dan jasa yang boleh dikonsumsi yaitu surah al-Baqarah ayat 168:

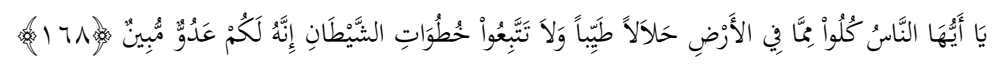

Hai sekalian manusia, makanlah yang halal lagi baik dari apa yang terdapat di bumi, dan janganlah kamu mengikuti langkah-langkah syaitan; karena sesungguhnya syaitan itu adalah musuh yang nyata bagimu.

Imam (ar-Razi, 2003) menafsirkan kata halalan adalah kebolehan dan terlepas dari unsur yang berbahaya. Sedangkan kata tayyib adalah lezat, baik dan bukan milik orang lain. Sedangkan haram adalah kotor, tidak baik seperti bangkai, darah khamr, dan sesuatu yang dapat merusak.

Tafsir tersebut menjelaskan bahwa makanan yang boleh adalah halal, enak dan memiliki gizi sedangkan produk seperti kosmetik dan obat-obatan selain berasal dari bahan-bahan baik yang tidak membahayakan. Makanan dan produk halal juga harus diproduksi secara baik yaitu kalau makanan seperti daging dipotong secara halal kalau produk lainnya diproduksi secara higienis, bahannya tidak berasal dari eksploitasi seperti menyebabkan kepunahan, merusak lingkungan seperti membuang limbahnya pada sembarang tempat sehingga merusak habitat lainnya.

Selanjutnya lebih rinci lagi makanan dan produk yang haram dijelaskan pada surah alBaqarah ayat 173 yaitu:

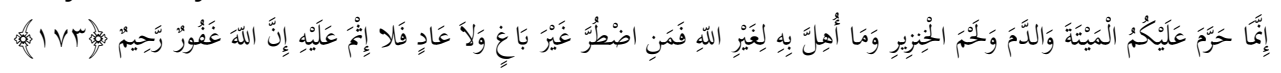

Sesungguhnya Allah hanya mengharamkan bagimu bangkai, darah, daging babi dan binatang yang (ketika disembelih) disebut (nama) selain Allah. Tetapi barangsiapa dalam keadaan terpaksa (memakannya) sedang ia tidak menginginkannya dan tidak (pula) melampaui batas, maka tidak ada dosa baginya. Sesungguhnya Allah Maha Pengampun lagi Maha Penyayang.

Imam (ar-Razi, 2003) menjelaskan ayat ini bahwa macam-macam yang diharamkan diantaranya adalah bangkai. Bangkai adalah sesuatu yang mati tidak 


\section{Vol 1 No 2 (2018) 245-255 P-ISSN 2620-295 E-ISSN 2747-0490 DOI: $1047467 /$ elmal.v2i2.544}

disembelih atau disembelih dengan cara yang tidak sesuai dengan syari'at Islam. Selain itu yang diharamkan adalah darah mengalir.

QS. Thaahaa:81 menjelaskan tentang makanan dan produk yang diperoleh secara baik yakni:

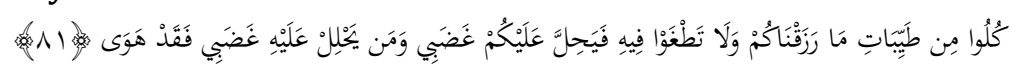

"Makanlah di antara rezeki yang baik yang telah kami berikan kepadamu, dan janganlah melampaui batas padanya, yang menyebabkan kemurkaan-Ku menimpamu. Dan barang siapa ditimpa oleh kemurkaan-Ku, maka sesungguhnya binasalah ia"(QS. Thaahaa:81)

Penjelasan (At-Thabari, 2000) dalam tafsirnya bahwa Allah menyuruh kepada bani Israil supaya mereka memakan di antara rezeki yang baik, yang lezat cita rasanya dan yang telah Allah karuniakan kepada mereka, jangan sekali-kali mereka menyalahgunakanya, seperti menafkahkannya dengan boros, tidak mensyukurinya, mendermakan kepada kemaksiatan, dan lain-lain. Karena kalau demikian berarti mereka telah mengundang kemurkaan Allah yang akan menimpakan siksaannya. Celaka dan binasalah orang-orang yang ditimpa kemurkaan Allah.

(al-Arif, NR \& Amalia, E, 2014) juga menjelaskan dalam bukunya tentang etika mengkonsumsi makanan dan produk halal yaitu bahwa dalam kerangka acuan Islam, barang-barang yang dapat dikonsumsi hanyalah barang-barang yang menunjukkan nilainilai kebaikan, kesucian, keindahan, serta menimbulkan kemaslahan untuk ummat baik secra materil maupun spiritual. Sebaliknya, benda-benda yang buruk, tidak suci (najis), tidak bernilai, tidak dapat digunakan dan juga tidak dapat dianggap sebagai barangbarang konsumsi dalam Islam serta dapat menimbulkan kemudaratan apabila dikons pendapat (al-Qardawi, 1993) dasar pertama yang ditetapkan Islam yaitu asal sesuatu yang diciptakan Allah adalah halal dan mubah. Tidak ada satupun yang haram , kecuali karena ada nash yang sah dan tegas dari syar'I (yang berwenang membuat hukum itu sendiri yaitu Allah dan Rasul) yang mengharamkannya. Kaitannya dengan penelitian ini bahwa hukum asalnya mengkonsumsi makanan dan produk lainnya diperbolehkan selagi tidak ada larangannya secara syar'i.

Berdasarkan landasan diatas maka yang dimaksud dengan makanan dan produk halal adalah suatu makanan yang terhindar dari yang diharamkan, lezat dan bergizi, produk tidak mengandung najis, bahan-bahan yang berbahaya, serta bersih dari kotoran yang dapat memberi nilai-nilai kebaikan, kesehatan, keamanan, kesucian, keindahan, serta tidak menimbulkan kemudratan bagi yang lainnya akan tetapi menimbulkan kemaslahatann untuk ummat baik secra materil maupun spiritual.

\section{Kesadaran Masyarakat Mengkonsumsi Makanan dan Produk halal}

Kesadaran (consciousness) menurut (Zeman, 2001) berasal dari bahasa Latin yaitu conscio yang dibentuk dari kata cum artinya with (dengan) dan scio yang berarti know (tahu). Menurutnya ada tiga maksud dari kesadaran yaitu 1) kesadaran adalah mind (pikiran); 2) kesadaran adalah pengalaman; 3) kesadaran dalam keadaan terjaga/bangun.

Berbeda dengan pendapat (Natsoulas, 1999) menurutnya terdapat enam makna kesadaran yaitu 1) pengetahuan atau keyakinan internal; 2) pengetahuan bersama; 


\section{Vol 1 No 2 (2018) 245-255 P-ISSN 2620-295 E-ISSN 2747-0490 DOI: $1047467 /$ elmal.v2i2.544}

3)mengenali perasaan atu tindakan sendiri; 4)kondisi mental yang sedang menyadari sesuatu; 5) dalam kondisi terjaga/bangun secara normal; dan 6) kesatuan pribadi yakni totalitas pikiran, impresi, dan perasaan yang membentuk perasaan sadar. Pendapat (Schiffman L.G,. \& Kanuk, L.L, 1997) bahwa anggota dari berbagai keputusan pembelian kelompok agama dipengaruhi oleh agama mereka, orientasi, identitas, pengetahuan, dan kepercayaan.

Berdasarkan pendapat-pendapat para ahli diatas, maka dapat dipahami bahwasanya keasadaran adalah memiliki dorongan (motif) berdasarkan kepercayaan, pengetahuan, pengalaman atau informasi yang didapatkan tentang apa itu makanan dan produk halal. Berdasarkan kepercayaan, pengetahuan, pengalaman atau informasi seseorang mengetahui bahawa produk halal adalah suatu produk tidak mengandung najis, aman dari bahan yang berbahaya, bersih, sehat, serta menimbulkan kemaslahatan untuk ummat baik secara materil maupun spiritual.

\section{Kepercayaan}

Seperti pendapat (Schiffman L.G.. \& Kanuk, L.L, 1997) diatas bahwa kepercayaan dalah salah satu yang memberikan kesadaran dalam membeli produk. Agama menurut (Johnstone., 1975) adalah sistem kepercayaan dan praktik yang dengannya sekelompok orang menafsirkan dan meresponsnya apa yang mereka rasakan adalah supranatural dan sakral. Pengetahuan agama atau kepercayaan adalah pedoman terbaik untuk mengetahui makanan dan produk halal yang boleh dikonsumsi.

Beberapa kepercayaan memberlakukan beberapa pembatasan konsumsi. Larangan daging babi dan bukan daging hasil pembantaian ritual dalam Yudaisme dan Islam, dan daging babi dan daging sapi dalam agama Hindu dan Budha, ketenangan pikiran bagi komunitas Vegetarian, kecuali agama Kristen yang tidak memiliki tabu dalam mengkonsumsi, Meskipun hukum diet yang diberlakukan oleh beberapa agama mungkin agak ketat, Orang yang mengikuti biasanya cukup besar. Louren dan Tournis menemukan kata-kata pendiri industri kosmetik dalam hasil penelitian mereka bahwa halal adalah titik penjualan unik PHB (dengan orang Halal mungkin menganggap itu hanya untuk muslim, tapi sebenarnya tidak, justru sebaliknya. (Kami hanya berusaha membantu orang untuk memahami apa yang dimaksud halal mereka tidak berpikir, 'Oh itu Halal bukan untuk saya,' mereka berpikir 'Halal' dan melihatnya sebagai jaminan (Aoun, Isabelle; \& Tournois, Laurent, 2015).

Menurut pendapat (Chapra, 2008) bahwa dasar utama peraturan Islam adalah Shari'ah. Shari'ah merujuk pada nilai-nilai (values) dan institusi atau peraturan untuk membuat masyarakat memenuhi kewajiban-kewajibannya dan mencegah kerusakan sosial untuk memastikan penegakan keadilan, pembangunan dan tercapainya well-being untuk semua. Shari'ah Islam mengatur segala aspek kehidupan termasuk prilaku konsumsi. Termasuk mengatur makanan dan produk yang boleh digunakan oleh ummat Islam yaitu makanan dan produk halal.

Temuan (Ambali, A. R., \& Bakar, A. N, 2014) bahwa salah satu yang menjadikan meningkatnya permintaan akan konsumsi halal adalah alasan kesehatan.. Pemerintah, 


\section{Vol 1 No 2 (2018) 245-255 P-ISSN 2620-295 E-ISSN 2747-0490 DOI: $1047467 /$ elmal.v2i2.544}

produsen maupun pemakai kosmetik harus mengetahui bahwa konsep halal dalam makanan dan produk halal dapat dijadikan sebagai simbol global untuk menjamin kualitas gaya hidup konsumen di dunia. Karena halal memiliki nilai-nilai yang positif bagi semua line masyarakat. Seperti sehat, bersih, serta terhindar dari bahan-bahan yang berbahaya.

Menurut Mu'rifah (2017), kesehatan adalah segala usaha dan tindakan seseorang untuk menjaga, memelihara, dan meningkatkan derajat kesehatannya sendiri dalam batas-batas kemampuannya, agar mendapatkan kesenangan hidup dan mempunyai tenaga kerja yang sebaik-baiknya. Sedangkan menurut UU No.36 tahun 2009 Tentang Kesehatan, kesehatan adalah keadaan sehat, baik secara fisik, mental, spiritual maupun sosial yang memungkinkan setiap orang untuk hidup produktif secara sosial dan ekonomi.

Berdasarkan pengertian diatas bahwa bahwa kesehatan itu merupakan keadaan yang sejahtera dari badan, jiwa dan sosial yang diupayakan melalui tindakan menjaga, memelihara, dan meningkatkan derajat kesehatannya sehingga bisa hidup produktif dan mempunyai tenaga yang sebaik-baiknya. Maka dapat disimpulkan bahwa alasan kesehatan merupakan salah satu yang memberi kesadaran terhadap konsumen untuk menggunkan makanan dan produk halal, karena halal merupakan symbol dari kebersihan, keamanan dan kualitas yang dapat dipakai semua orang.

\section{METODE PENELITIAN}

Penelitian ini di lakukan pada mahasiswa STAIS Jam'iyah Mahmudiyah TanjungPura Langkat. Jenis penelitian yang dilakukan adalah penelitian Kuantitatif, dengan menggunakan populasi seluruh mahasiswa. Adapun jumlah sampel 50 orang yang diambil berdasarkan convenience sampling. Menyebarkan angket/ questioner sebagai metode pengumpulan data, maka dalam pengelolaan data peneliti menggunakan bantuan program software SPSS 20,0 windows. Untuk mengetahui pengaruh kepercayaan dan kesehatan terhadap kesadaran masyarakat mengkonsumsi makanan dan produk halal.

\section{HASIL DAN PEMBAHSAN}

\section{Uji Regresi Linear Berganda}

Berdasarkan hasil penyebaran kuesioner/angket dengan sampel 50 responden menyimpulkan bahwa Berdasarkan hasil analisis regresi berganda diperoleh persamaan sebagai berikut:

$$
\mathrm{Y}=-8,326+0,827 \mathrm{X}_{1}+0,468 \mathrm{X}_{2}+\mathrm{e}
$$

Nilai konstanta sebesar=-8,326 artinya jika variabel independent (kepercayaan dan kesehatan) sama dengan nol, maka kesadaran konsumen mengkonsumsi makanan dan produk halal akan meningkat sebesar -8,326. Koefisien regresi $\mathrm{X}_{1}$ sebesar 0,827 artinya jika variabel kepercayaan konsumen mengalami kenaikan sebesar 1 (satu-satuan) maka akan menaikan kesadaran konsumen pada makanan dan produk halal sebesar 0,827 (asumsi faktor lain tetap). Dan koefisien $\mathrm{X}_{2}$ sebesar 0,468 artinya jika variabel kesehatan 
Vol 1 No 2 (2018) 245-255 P-ISSN 2620-295 E-ISSN 2747-0490 DOI: 1047467/elmal.v2i2.544

mengalami kenaikan sebesar 1 (satu-satuan) maka akan menaikan kesadaran konsumen mengkonsumsi makanan dan produk halal sebesar 0,468 (asumsi faktor lain tetap). Dari uraian tersebut dapat disimpulkan bahwa kepercayaan dan kesehatan mempunyai pengaruh Terhadap kesadaran pada makanan dan produk halal.

\section{Uji Hipotesis}

Uji t

\begin{tabular}{|c|c|c|c|c|c|}
\hline \multicolumn{6}{|c|}{ Coefficients $^{a}$} \\
\hline \multirow[b]{2}{*}{ Model } & \multicolumn{2}{|c|}{$\begin{array}{l}\text { Unstandardized } \\
\text { Coefficients }\end{array}$} & \multirow{2}{*}{$\begin{array}{c}\text { Standardized } \\
\text { Coefficients } \\
\text { Beta } \\
\end{array}$} & \multirow[b]{2}{*}{$\mathrm{T}$} & \multirow[b]{2}{*}{ Sig. } \\
\hline & B & Std. Error & & & \\
\hline 1 (Constant) & $\begin{array}{r}- \\
8.326\end{array}$ & 2.533 & & -3.287 & .002 \\
\hline kepercayaan & .827 & .142 & .542 & 5.828 & .000 \\
\hline kesehatan & .468 & .104 & .418 & 4.495 & .000 \\
\hline
\end{tabular}

Berdasarkan tabel Coefficients diatas dapat di ketahui bahwa kepercayaan $\left(\mathrm{X}_{1}\right)$ memiliki nilai $\mathrm{t}$ hitung $>\mathrm{t}$ tabel $(5.828>1,677)$ dengan tingkat signifikan $0,000<0,05$. Artinya kepercayaan $\left(\mathrm{X}_{1}\right)$ berpengaruh signifikan terhadap kesadaran pada makanan dan produk halal $(\mathrm{Y})$, sedangkan kesehatan $\left(\mathrm{X}_{2}\right)$ memiliki nilai $\mathrm{t}_{\text {hitung }}>\mathrm{t}$ tabel $(4,495>1,677)$ dengan tingkat signifikan $0,000<0,05$. Artinya alasan kesehatan $\left(X_{2}\right)$ berpengaruh signifikan terhadap kesadaran pada makanan dan produk halal.

Uji F

\begin{tabular}{|l|l|r|r|r|r|r|}
\hline \multicolumn{7}{|c|}{ ANOVA $^{\text {a }}$} \\
\hline \multicolumn{2}{|l|}{ Model } & Sum of Squares & \multicolumn{1}{c|}{ df } & Mean Square & F & Sig. \\
\hline 1 & $\begin{array}{l}\text { Regressio } \\
\mathrm{n}\end{array}$ & 230.243 & 2 & 115.121 & 53.372 & $.000^{\mathrm{b}}$ \\
\cline { 2 - 7 } & Residual & 101.377 & 47 & 2.157 & & \\
\cline { 2 - 7 } & Total & 331.620 & 49 & & & \\
\hline
\end{tabular}

Sumber: Data Diolah Peneliti menggunakan SPSS 20,0 (2019)

Berdasarkan tabel diatas menunjukkan bahwa nilai $F_{\text {hitung }}>F_{\text {tabel }}(53,372>3,20)$ dan nilai signifikan $0,000<0,05$. Kriteria $F_{\text {hitung }}>F_{\text {tabel }}$ dan signifikan $<0,05$. Maka Ha diterima, artinya terdapat pengaruh yang signifikan antara kepercayaan dan kesehatan secara simultan terhadap kesadaran pada makanan dan produk halal.

Uji Koefisien Determinasi (R Square)

Model Summary


Vol 1 No 2 (2018) 245-255 P-ISSN 2620-295 E-ISSN 2747-0490 DOI: 1047467/elmal.v2i2.544

\begin{tabular}{|c|c|c|c|c|}
\hline Model & $\mathrm{R}$ & R Square & $\begin{array}{c}\text { Adjusted R } \\
\text { Square }\end{array}$ & $\begin{array}{l}\text { Std. Error of the } \\
\text { Estimate }\end{array}$ \\
\hline 1 & $.833^{a}$ & .694 & .681 & 1.469 \\
\hline
\end{tabular}

Berdasarkan hasil perhitungan pada tabel di atas dapat dilihat nilai R Square sebesar 0,694 atau sama dengan 69,4\%. Berarti model analisis yang digunakan mampu menjelaskan kepercayaan dan kesehatan terhadap kesadaran pada makanan dan produk halal. sebesar $69,4 \%$ sedangkan sisanya 30,6\% dipengaruhi oleh faktor lain yang tidak diteliti.

Dari uraian diatas dapat disimpulkan bahwa kepercayaan dan kesehatan mempunyai pengaruh Terhadap kesadaran pada makanan dan produk halal. Secara parsial kepercayaan $\left(\mathrm{X}_{1}\right)$ memiliki nilai $\mathrm{t}$ hitung $>\mathrm{t}$ tabel $(5.828>1,677)$ dengan tingkat signifikan $0,000<0,05$. Artinya keperca $\left(\mathrm{X}_{1}\right)$ berpengaruh signifikan terhadap kesadaran konsumen mengkonsusmsi makanan dan produk halal (Y) di STAIS Jam'iyah Mahmudiah Tanjung Pura Langkat Sumatera Utara. Menunjukkan bahwa nilai $F_{\text {hitung }}>F_{\text {tabel }}(53,372>3,20)$ dan nilai signifikan $0,000<0,05$. Kriteria $F_{\text {hitung }}>F_{\text {tabel }}$ dan signifikan $<0,05$. Maka Ha diterima, artinya terdapat pengaruh yang signifikan antara kepercayaan dan kesehatan secara simultan terhadap kesadaran pada makanan dan produk halal.

\section{Pembahasan}

Berdasarkan hasil penelitian, dapat diperoleh hasil bahwa untuk mengetahui kepercayaan dan kesehatan konsumen dalam mengkonsumsi produk halal di STAIS Jam'iayah Mahmudiyah Tanjung Pura Langkat. Terkait dengan tingkat maslahah, yang merujuk pada pendapat Asy-Syathibi tingkat maslahah yang merupakan konsep terpenting dalam berperilaku dan bersikap terhadap apa yang akan dikonsumsi. Kesadaran konsumen mengkonsumsi makanan dan produk halal di STAIS Jam'iyah Mahmudiyah Tanjung-Pura Langkat menunjukkan kesadaran sesuai dengan landasan nilai-nilai Islam yaitu sesuai dengan Maqasid Syariah yang tidak bertentangan dengan maslahah dharuriyah, hajiyat dan tahsiniyat yaitu menjaga agama, jiwa, akal, keturunan, dan harta.

Dalam riset ini maslahah dharuriyah, hajiyat dan tahsiniyat dapat dilihat bahwa konsumen mementingkan kepercayaannya dengan menjaga dan yakin mengkonsumsi produk halal, menjaga jiwa dan pikirannya yaitu dengan mementingkan kesehatan, serta menjaga keturunannya yaitu dengan yakin mengkonsumsi produk halal akan baik bagi keluarga dan diri sendiri disebabkan oleh kesadaran konsumen tentang manfaat produk yang akan dikonsumsi. Variabel kesehatan menunjukkan bahwa konsumen mengkonsumsi makanan dan produk halal dengan alasan bahwa makanan dan produk halal itu adalah makanan yang seharusnya lezat, terhindar dari zat-zat yang berbahaya seperti pewarna, dimasak secara bersih dan dipotong secara Islami. Temuan ini sejalan dengan pendapat Abu Bakr Ibn al-Arabin yaitu suatu yang pantas untuk dikonsumsi adalah yang baik bagi tubuh kita dan rasanya lezat dan dihalalkan oleh Allah SWT. (al- 


\section{Vol 1 No 2 (2018) 245-255 P-ISSN 2620-295 E-ISSN 2747-0490 DOI: $1047467 /$ elmal.v2i2.544}

'Arabi).

Temuan ini juga sejalan dengan temuan Sparks dan Shepherd (1992) serta Ajzen dan Fishbein (1975) yaitu terdapatnya pengaruh dan hubungan kesadaran konsumen terhadap kepercayaan konsumen. Temuan ini juga sesuai dengan yang dikemukakan Ramadhani bahwa bahwa kesadaran berasal dari kepercayaan.Temuan ini sejalan dengan pendapat Miller (2005) bahwa kesadaran adalah sekumpulan dari keyakinan tentang perilaku tertentu ditimbang dengan evaluasi dari kepercayaan. Selain itu dalam temuan (Ambali, A. R., \& Bakar, A. N, 2014) alasan kesehatan merupakan faktor paling esensial menumbuhkan kesadaran halal konsumen. Variabel kepercayaan dan kesehatan terhadap kesadaran konsumen mengkunsumsi makanan dan produk halal menguatkan penelitian-penelitian sebelumnya.

Temuan-temuan ini menunjukkan bahwa potensi industri halal sangat berpotensi baik di pasar nasional maupun internasional. Seperti yang dinyatakan (Mathew,. V., N., Raudah,. A. M,. \& Nurazizah,. S, 2014) konsep halal umumnya menjadi perhatian konsumen muslim. Namun dengan meningkatnya kepedulian terhadap kesehatan, makanan menjadi halal bisnis saat ini memiliki potensi besar dalam menangkap non muslim sebagai pasar sasaran. Konsep halal makanan saat ini adalah melampaui pemahaman nilai agama saja. Ini mewakili kebersihan dan kualitas makanan dikonsumsi. Hasil penelitian tersebut dapat memberikan wawasan bagi produsen makanan halal untuk melirik non muslim konsumen sebagai salah satu target pasar industry makanan halal.

\section{Kesimpulan}

Berdasarkan hasil penelitian dan pembahasan maka dapat disimpulkan bahwa secara parsial hasil penelitian menunjukkan bahwa kepercayaan $\left(\mathrm{X}_{1}\right)$ dan kesehatan $\left(\mathrm{X}_{2}\right)$ berpengaruh positif, kepercayaan $\left(X_{1}\right)$ dimana memiliki nilai $t_{\text {hitung }}>t_{\text {tabel }}(5.828>1,677)$ dengan tingkat signifikan $0,000<0,05$, artinya kepercayaan $\left(X_{1}\right)$ berpengaruh signifikan terhadap kesadaran konsumen mengkonsumsi makanan dan produk halal (Y) di STAIS Jamiyah Mahmudiyah Tanjung-Pura Langkat. Kesehatan $\left(\mathrm{X}_{2}\right)$ memiliki nilai $\mathrm{t}_{\text {hitung }}>\mathrm{t}$ tabel $(4,495>1,677)$ dengan tingkat signifikan $0,000<0,05$, artinya kesehatan $\left(X_{2}\right)$ berpengaruh signifikan terhadap kesadaran konsumen mengkonsumsi makanan dan produk halal di STAIS Jam'iyah Mahmudiyah Tanjung-Pura Langkat dan secara Simultan menunjukkan bahwa nilai $F_{\text {hitung }}>F_{\text {tabel }}(53,372>3,20)$ dan nilai signifikan $0,000<0,05$. Kriteria $\mathrm{F}_{\text {hitung }}>\mathrm{F}_{\text {tabel }}$ dan signifikan $<0,05$. Maka Ha diterima, artinya terdapat pengaruh yang signifikan antara kepercayaan dan kesehatan secara simultan terhadap kesadaran makanan dan produk halal. Berdasarkan nilai R Square sebesar 0,694 atau sama dengan $69,4 \%$. Berarti model analisis yang digunakan mampu menjelaskan kepercayaan dan kesehatan terhadap kesadaran mengkonsumsi makanan dan produk halal sebesar 69,4\% sedangkan sisanya 30,6\% dipengaruhi oleh faktor lain yang tidak diteliti.

\section{Saran}

Berdasarkan kesimpulan yang diperoleh, maka peneliti memberikan saran kepada peneliti selanjutnya dengan kesamaan variabel, mencoba untuk menggunakan metode 


\section{Vol 1 No 2 (2018) 245-255 P-ISSN 2620-295 E-ISSN 2747-0490 DOI: $1047467 /$ elmal.v2i2.544}

yang berbeda sebagai pembanding dan menggunakan lebih banyak lagi variabel-variabel yang mungkin dapat mempengaruhi kesadaran konsumen makanan dan produk halal. sehingga dapat memberikan hasil penelitian yang lebih baik.

\section{DAFTAR PUSTAKA}

al-'Arabi, A. B. (n.d.). Ahkam Al-Qur'an. Beirut: Dar al-Fikr.

al-Arif, NR \& Amalia, E. (2014). Teori Mikroekonomi: suatu Perbandingan Ekonomi Islam dan Ekonomi Konvensional. Jakarta: Kencana Prenada Media Group, cet ke-2,h.9.

al-Qardawi, Y. (1993). Halal dan Haram Dalam Islam (Terjemahan Muhammad Hamidy). Bangil: Bina Ilmu, h. 19.

al-Qardhawi, Y. (1997). Norma dan Etika Ekonomi Islam. Terjemahan Zainul Arifin. Jakarta: Gema Insani Press.

Ambali, A. R., \& Bakar, A. N. (2014). People's Awareness on Halal Foods and Products: Potential Issues for Policy Makers. The Journal Of International Procedia-Social and Bahavioral Sciences, 121, 3-25.

Aoun, I., \& Tournois, L. (2015). Building Holistic Brands: an exploratory stdudy of Halal Cosmetics. Journal of Islamic Marketing.

ar-Razi, F. (2003). Tafsir al-Kabir Mafatih al-Ghaib. Mesir, Cairo: Maktabah at-Taufiqiyah.

At-Thabari, A. J. (2000). Jami' al-Bayan fi Takwil al-Qur'an. Lebanon. Lebanon: Muassasah: ar-Risalah, h.345.

Baird, Carolyn Heller, \& Parasnis, Gautam. . (2011). Strategy and Leadership. From Social Media To Social Customer Relationship. Management, 39, 30-37.

Chapra, M. U. (2008). Ibn Khaldun Teori Does it help ecplain the Low Performance of The Present -Day Moeslem World? Jurnal Sosial Ekonomi, 836-863.

Johnstone. (1975). Religion and society in interaction: the sociology of religion. PrenticeHall.

Mathew,. V., N., Raudah,. A. M,. \& Nurazizah,. S. (2014). Acceptance on Halal Food among Non Muslim Consumers. Procedia- Social and Behavioral Sciences, 262-271.

Mu'rifah. (2007). Materi Pokok Pendidikan Kesehatan. Jakarta: Universitas Terbuka. Jakarta: Universitas Terbuka.

MUI, F. M. (2009). Tentang Penetapan Produk Halal.

Natsoulas, T. (1999). The Concepts of Consciousness: The General State Meaning. Journal for the Theory for Social Behavior, 59-87. 
Vol 1 No 2 (2018) 245-255 P-ISSN 2620-295 E-ISSN 2747-0490 DOI: 1047467/elmal.v2i2.544

Schiffman L.G,. \& Kanuk, L.L. (1997). Consumer Behaviour. N.J Prentice Hall.

Zeman, A. (2001). Consciousness. Brain, 124, 1263-1289. 